\title{
Strategi Pembentukan Tambrauw Sebagai Kabupaten Konservasi Di Papua
}

\author{
Sepus M Fatem ${ }^{1 *}$, San Afri Awang ${ }^{2}$, Ahmad Maryudi² Satyawan Pudyatmoko², Jonni \\ Marwa $^{3}$, Devi Manuhua ${ }^{3} \&$ Salmon Lembang ${ }^{3}$ \\ 1,2Fakultas Kehutanan UGM Jogjakarta; Email: sepusfatem@yahoo.com \\ 1,3Fakultas Kehutanan Universitas Papua, Jl. Gunung Salju Amban, Manokwari Papua Barat
}

\begin{abstract}
ABSTRAK
Tambrauw merupakan kabupaten di Papua Barat yang menempatkan kebijakan konservasi sebagai domain pembangunan daerah. Penelitian ini bertujuan merancang strategi bagi pembentukan Tambrauw sebagai Kabupaten Konservasi. Penelitian berlangsung sejak bulan oktober-November 2017, menggunakan pendekatan SWOT untuk analisis kekuatan dan kelemahan (faktor Internal) dan peluang dan ancaman (faktor eksternal). Hasil penelitian menunjukkan bahwa Tambrauw layak sebagai Kabupaten Konservasi, dimana posisinya berada pada kwadran I. Artinya bahwa terdapat kekuatan dan peluang sebagai faktor kunci pembentukan kabupaten Konservasi. Kelayakan sebagai kabupetan konservasi juga terlihat melalui hasil analisis faktor internal dan eksternal, dimana Tambrauw dimungkinkan menjadi kabupaten konservasi dengan nilai evaluasi faktor internal 3.20 dan ekternal sebesar 2.75. Meskipun faktor kelemahan dan keterancaman memiliki potensi cukup besar, namun melalui 4 pilihan strategi yang ditetapkan diyakini akan membantu pemerintah Kabupaten Tambrauw memperkecil ancaman dan kelemahan dimaksud.
\end{abstract}

Kata kunci: Kabupaten konservasi; Strategi Pembentukan, Tambrauw

\section{ABSTRACT}

Tambrauw regency of West Papua province, has been placing conservational policy as domain of the regional development. This study is intended to design a strategy for establishing Tambrauw as a Conservation Region. This research was conducted from October to November 2017, by employing SWOT analysis to analyse strength and weaknesses (internal factors), and opportunity and threats (external factors). The results show that the quadran I of Tambrauw regency is decent to become a Conservation Region which means that it has potential and opportunity for the establishment of Conservation Region. The feasibility of becoming a conservation region can be seen through the results' analysis of internal and external factors with the evaluation value of 3.20 and 2.75, respectively. Despite a considerable weaknesses and threats elements, these issues could be minimized by implementing four chosen schemes by the Government of Tambrauw.

Key words: Conservation Regency; Establishment strategy; Tambrauw

Citation: Fatem , S. M., Awang, S. A., Maryudi, A., Pudyatmoko, S., Marwa, J., Manuhua, D., dan Lembang, S. (2019). Strategi Pembentukan Tambrauw Sebagai Kabupaten Konservasi Di Papua. Jurnal Ilmu Lingkungan, 17(2),373-387, doi:10.14710/jil.17.2.373-387

\section{Pendahuluan}

\subsection{Latar Belakang}

Istilah hutan konservasi di Indonesia merujuk pada suatu kawasan hutan yang diproteksi atau dilindungi. Proteksi atau perlindungan tersebut bertujuan untuk melestarikan hutan dan kehidupan yang ada didalamnya agar bisa menjalankan fungsinya secara maksimal. Titik awal sejarah konservasi di Indonesia dimulai sejak kongres ke 3 Taman Nasional dan kawasan yang dilindungi sedunia pada oktober 1982 di Bali (Mackinnon et al
1993). Bersamaan dengan kongres tersebut, pemerintah Indonesia mendeklarasikan 11 taman nasional (Soemarwoto, 2004). Era ini menjadi tonggak awal dikenalkannya taman nasional di Indonesia, namun masih mengadopsi pola pengelolaan dari Taman Nasional Yellowstone, yang mengedepankan pendekatan pengamanan (security approach) dengan menggutamakan kepentingan konservasi diatas segalanya (Jepson dan Whittaker, 2002)

Pengertian hutan konservasi menurut Undang-Undang No.41 Tahun 1999 Tentang Kehutanan adalah kawasan hutan dengan ciri khas tertentu, yang mempunyai fungsi pokok 
pengawetan keanekaragaman tumbuhan dan satwa serta ekosistemnya. Hutan konservasi terdiri dari: Kawasan Hutan Suaka Alam (KSA) berupa Cagar Alam, dan Suaka Margasatwa; Kawasan Hutan Pelestarian Alam (KPA) berupa Taman Nasional, Taman Hutan Raya (Tahura) dan Taman Wisata Alam (TWA) dan taman buru. Kawasan Hutan Suaka Alam adalah hutan dengan ciri khas tertentu yang mempunyai fungsi pokok sebagai kawasan pengawetan keanekaragaman tumbuhan dan satwa serta pemanfaatan secara lestari sumber daya alam hayati dan ekosistimnya. Papua, sejak tahun 1990 menjadi tonggak awal gerakan konservasi dimulai. Diduga kuat bahwa pembentukan kawasan konservasi di wilayah ini tidak terlepas dari potensi Papua sebagai salahsatu wilayah tropis terbesar keragaman hayati dan budaya yang tinggi di dunia (Petocz 1989; Wikramanayake 2001). Berbagai usulan penetapan kawasan konservasi ini mendapat pengaruh dari berbagai aktor internasional seperti IUCN, WWF dan CI.

\subsection{Rumusan Masalah}

Tambrauw merupakan Kabupaten pemekaran di Papua Barat sejak tahun 2008 dengan luas wilayah $11.529,182 \mathrm{Km}^{2}$, terletak di bagian utara wilayah Kepala Burung utara Provinsi Papua Barat. Wilayah ini merupakan kabupaten dengan kawasan hutan yang sangat luas dengan proporsi hutan konservasi dan hutan lindung hingga $80 \%$ sesuai Surat Keputusan Menteri Kehutanan Nomor 783/II/2014 tentang peta fungsi hutan Provinsi Papua Barat (Bappeda Tambrauw, 2014).

Disisi lain, secara budaya dan adat istiadat, Pegunungan Tambrauw merupakan rumah tradisional suku-suku asli dan pusat peradaban "Pendidikan Inisiasi Wuon " sebagai praktek konservasi alam secara tradisional di kepala burung Papua. Hubungan ini bersifat timbal balik bahkan mistik dan tidak dapat dipisahkan dari kehidupan ketradisionalan, sehingga hutan dansegala isinya sangat dijaga dan dihargai eksistensinya oleh suku asli. Dengan wilayah yang luas, kekayaan sumber daya alam yang melimpah, keragaman budaya dan penghidupan masyarakat yang hidup didalamnya, Tambrauw menjadi bagian di Papua yang menantang untuk dikelola dalam rangka mewujudkan manfaat pembangunan bagi masyarakat.

Fakta diatas mendorong pemerintah Daerah terus berupaya untuk menemukan bentuk pengaturan pengelolaan sumber daya alam yang baik, berkelanjutan dan bermanfaat yang terintegrasi melalui tata kelola pemerintahan. Oleh sebab itu Kabupaten konservasi menjadi pilihan politik dimana telah tertuang dalam misi kelima yakni Menjaga Lingkungan dengan menetapkan Tambrauw sebagai kabupaten konservasi (Asem et al, 2013; Bappeda Tambrauw 2014; Fatem dan Asem, 2015; Fatem et all 2018).

Kabupaten Konservasi adalah wilayah administrasi pemerintahan yang melaksanakan pembangunan mengacu upaya pelestarian, perlindungan serta pemanfaatan keanekaragaman hayati dan ekosistem (Kartodiharjo, 2005). Definisi ini kemudian dikembangkan dengan pengertian yakni sebuah tatakelola pemerintahan adaptif yang melaksanakan pembangunan bertumpu pada upaya konservasi aspek sosial- budaya, ekonomi dan ekologi (Fatem, 2018). Kebijakan ini akan mewajibkan sebuah kerangka kerja pemerintah yang mendukung mata pencaharian lokal, memfasilitasi pertumbuhan ekonomi, dan melindungi keanekaragan hayati yang signifikan secara global, serta jasa ekosistem (termasuk penyerapan karbon).

Komitmen Kabupaten Tambrauw sebagai Kabupaten Konservasi memberikan peluang yang strategis bagi pemerintah daerah, provinsi maupun pusat untuk memastikan agar pengelolaan sumberdaya alam sebagai modal pembangunan dapat diselenggarakan secara berkelanjutan serta memberikan manfaat yang adil bagi masyarakat, terutama masyarakat adat antar generasi.

Meskipun komitmen politik pemerintah Kabupaten Tambrauw cukup tinggi, namun munculah pertanyaan lanjutan sejauh mana daerah memiliki strategi dalam mengimplementasikan kebijakan kabupaten konservasi tersebut. Berdasarkan argumentasi dan fakta diatas, maka dipandang perlu dilakukan penelitian guna menganalisis faktorfaktor kunci apa saja yang paling berpenggaruh dari semua aspek yang ada untuk mengembangkan Tambrauw sebagai Kabupaten Konservasi.

\subsection{Tujuan}

Berdasarkan latar belakang dan masalah yang telah diuraikan diatas maka penelitian ini bertujuan untuk:

1. Menganalisis faktor internal dan faktor eksternal yang berpotensi berpengaruh terhadap pembentukan Tambrauw sebagai Kabupaten Konservasi

2. Menyusun strategibagi pembentukan Tambrauw sebagai Kabupaten Konservasi 


\section{Metodologi Penelitian}

2.1. Lokasi dan Waktu

Penelitian dilaksanakan di Kabupaten Tambrauw, Povinsi Papua Barat, sebagaimana dapat dilihat pada Gambar 1. Sedangkan penelitian dilakukan dari Bulan Oktober - Desember 2017.

Kampung dan distrik pengambilan data tersaji pada gambar 1 peta.
Pengambilan data dilakukan di pada 76 responden dari 11 kampung dari 7 distrik di Kabupaten Tambrauw.

\subsection{Objek dan Subjek Penelitian}

Objek penelitian adalah kebijakan Tambarauw sebagai Kabupaten Konservasi. Sedangkan subjek penelitian dapat dilihat pada tabel 1 .

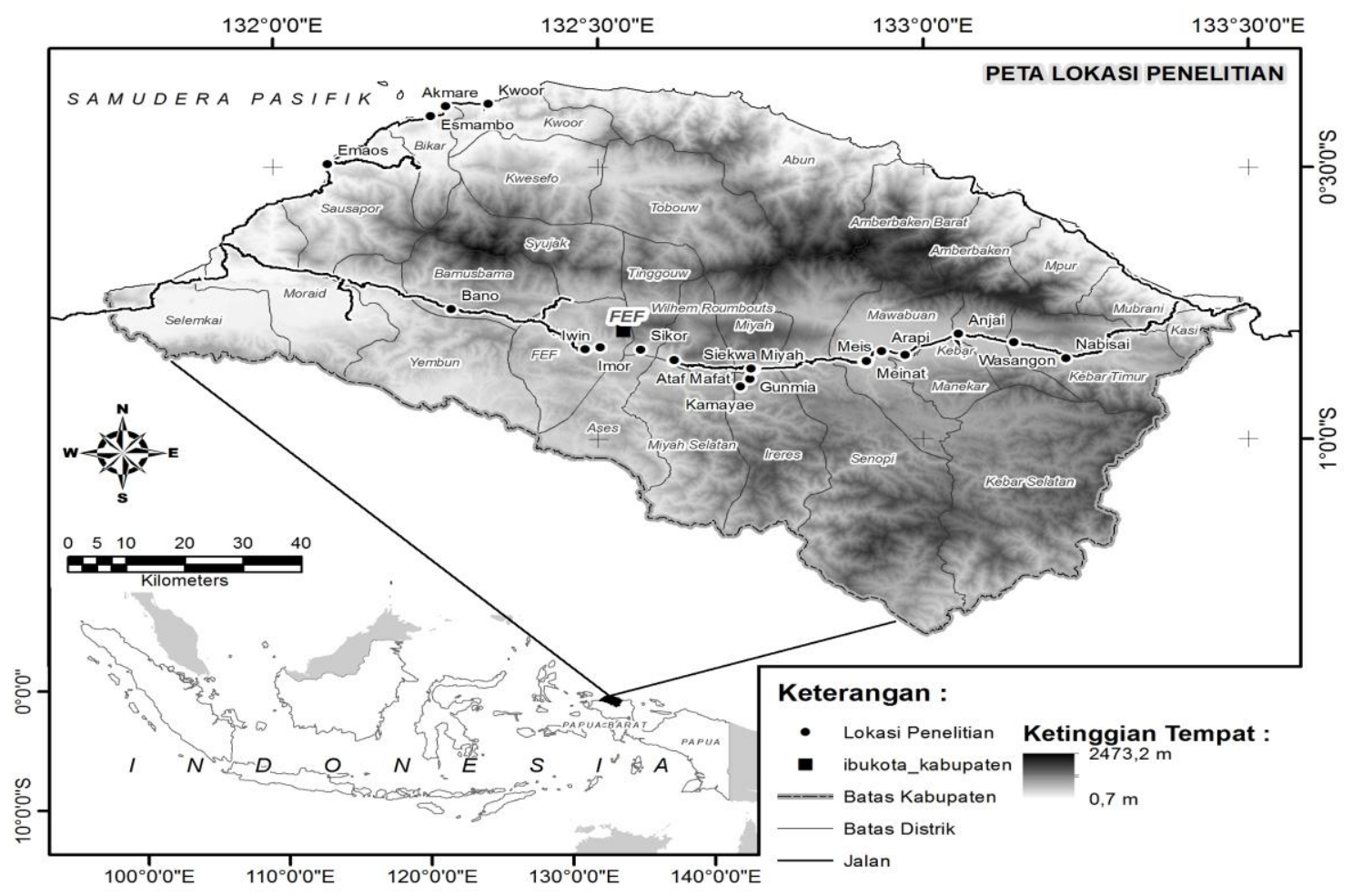

Gambar 1. Peta Lokasi Penelitian

Tabel 1. Jumlah Responden Penelitian

\begin{tabular}{|c|c|}
\hline Kelompok & Jumlah Responden \\
\hline Masyarakat adat & 40 orang \\
\hline PNS (Provinsi/kabupaten Tambrauw/Akademisi) & 30 orang \\
\hline Pimpinan Lembaga Swadaya Masyarakat (NGO) & 6 orang \\
\hline Jumlah & 76 orang \\
\hline
\end{tabular}

\subsection{Pengumpulan dan Analisis Data}

Data yang di kumpulkan meliputi data primer dan data sekunder. Data primer dikumpulkan dengan cara wawancara semi struktural dan pengamatan lapangan. Data tersebut antara lain: Databiofisik kawasan, sarana dan prasarana pendukung, persepsi masyarakat dan manfaat sosial-ekonomi. Sedangkan data sekunder berupa dokumen diperoleh dari instasi pemerintah di Kabupaten Tambrauw yang berkaitan dengan Tambrauw sebagai Kabupaten Konservasi, seperti; Profil Kabupaten Tambrauw, Laporan Penyelengaraan Pemerintah Daerah (LPPD) Kabupaten Tambrauw 2012-2016; analisis programprogram kerja Pemerintah Kabupaten 
Tambrauw yang berkaitan dengan adanya Kabupaten Konservasi serta analisis program kerja LSM/NGO yang berada di Kabupaten Tambrauw. Pengambilan data wawancara dilakukan pula di beberapa OPD Provinsi Papua Barat, BBKSDA Papua Barat dan Akademisi Fakultas Kehutanan Unipa Manokwari, sebagaimana tersaji pada lampiran 1. Data yang

\section{Hasil dan Pembahasan \\ 2.1. Evaluasi Faktor Kunci}

Kabupaten Tambrauw merupakan kabupaten yang sangat strategis untuk upaya konservasi sumberdaya alam, perlindungan sistem budaya dan adat maupun adaptasi dan mitigasi perubahan iklim global. Dalam upaya mewujudkan Tambrauw sebagai Kabupaten Konservasi, maka identifikasi faktor kunci (critical factor) sangat penting dilakukan. Faktor-faktor kunci itu, baik internal utama dan dikumpulkan kemudian dianalisis menggunakan teknik SWOT. Analisis SWOT merupakan proses yang sebelum direncanakan terlebih dahulu merinci keadaan lingkungan internal dan eksternal guna mengetahui faktor-faktor yang merupakan kunci keberhasilan kedalam kategori kekuatan (strengths), kelemahan (weaknesses), peluang (opportunities) dan ancaman (threats).

eksternal utama meliputi: Kekuatan (Strength, Kelemahan (Weakness), Peluang (Opportunities) dan Ancaman (Threat) (Nur Sumedi et al.2012). Dalam penelitian, diperoleh 7-10 faktor ekternal dan internal pembentukan Kabupaten konservasi. Selanjutnya dari faktor-faktor tersebut, dilakukan perhitungan untuk melihat total nilai bobot (TNB). Dari total nilai bobot tersebut, ditentukan 3 faktor kunci keberhasilan (FKK) internal berdasarkan nilai tertinggi TNB dimaksud. Lampiran 2.

Tabel 2. Evaluasi Faktor Internal (EFI) Pembentukan Kabupaten Konservasi

\begin{tabular}{lccc}
\multicolumn{1}{c}{ Faktor Internal } & Bobot & Rating & $\begin{array}{c}\text { Skor (Bobot x } \\
\text { Rating) }\end{array}$ \\
\hline $\begin{array}{l}\text { Luas wilayah 77\% Kawasan konservasi } \\
\begin{array}{l}\text { Komitmen Politik Pemerintah Daerah melalui visi dan } \\
\text { misi Pemerintah }\end{array}\end{array}$ & 0.30 & 4 & 1.20 \\
$\begin{array}{l}\text { Tingginya potensi wisata yang dapat dikelola menjadi } \\
\text { objek wisata }\end{array}$ & 0.10 & 4 & 1.20 \\
$\begin{array}{l}\text { Pengetahuan masyarakat \& OPD masih kurang terkait } \\
\text { Kabupaten Konservasi. }\end{array}$ & 0.10 & 1 & 0.40 \\
$\begin{array}{l}\text { Kelembagaan adat belum terstruktur baik. } \\
\text { Kurangnya pengawasan dan kontrol BBKSDA terhadap } \\
\text { aktivitas ilegal. }\end{array}$ & 0.10 & 2 & 0.10 \\
\hline
\end{tabular}

Sumber: Hasil Olahan data Primer, 2018

Dari faktor kunci yang diidentifikasi, terdapat 3 faktor utama sebagai "Evaluasi Faktor Internal

" Ketiga faktor tersebut antara lain: luas kawasan konservasi sekitar $77 \%$, komitmen politik yang kuat melalui visi-misi pembangunan daerah, potensi wisata sebagai sumber PAD Kabupaten. Sementara 3 faktor internal yang menjadi kelemahan antara lain; rendahnya pengetahuan aparat OPD dan masyarakat tentang kebijakan Kabupaten Konservas, kelembagaan adat belum terstrukur baik serta rendahnya kontrol dan pengawasan dari BBKSDA Papua Barat terhadap kawasan konservasi. Nilai hasil evaluasi EFI menujukkan nilai 3.20. Meskipun terdapat faktor kelemahan dalam proses pembentukan Kabupaten
Konservasi, namun dapat tertutupi oleh faktor kekuatan. Dengan demikian dapat dikatakan bahwa faktor internal sangat mendukung pembentukan Tambrauw Sebagai Kabupaten Konservasi yang ditunjukkan dengan nilai 3.20. Hasil identifikasi faktor internal dan eksternal dalam penelitian diperoleh 7-10 faktor ekternal dan internal yang terkait erat dengan pengembangan Tambrauw sebagai Kabupaten konservasi. Tahap berikutnya dilakukan perhitungan untuk melihat total nilai bobot (TNB) dari faktor-faktor eksternal tersebut. Selanjutnya, ditentukan 3 faktor kunci keberhasilan (FKK) berdasarkan nilai tertinggi TNB dimaksud. 
Tabel 3. Evaluasi Faktor Eksternal (EFE) pembentukan Kabupaten Konservasi

\begin{tabular}{|c|c|c|c|}
\hline Faktor Eksternal & Bobot & Rating & $\begin{array}{l}\text { Skor (Bobot } x \\
\text { Rating) }\end{array}$ \\
\hline \multicolumn{4}{|l|}{ Peluang } \\
\hline Menjadi destinasti wisata di Papua Barat. & 0.35 & 4 & 1.40 \\
\hline $\begin{array}{l}\text { Adanya kebijakan pembuatan KPH (Kesatuan Pengelolan } \\
\text { Hutan) }\end{array}$ & 0.20 & 3 & 0.60 \\
\hline & \multicolumn{3}{|c|}{ Ancaman } \\
\hline Degradasi kearifaan lokal akibat Era-globalisasi. & 0.05 & 2 & 0.10 \\
\hline Berubah-ubahnya kebijakan pemerintah pusat-daerah. & 0.05 & 2 & 0.10 \\
\hline \multirow{2}{*}{ Pencurian Satwa Liar dan tumbuhan dari oleh pihak luar. } & 0.25 & 1 & 0.25 \\
\hline & 1,00 & & 2.75 \\
\hline
\end{tabular}

Hasil Olahan data Primer, 2018

Hasil EFE menunjukkan nilai 2.75 (Tabel 2). Nilai tersebut dibawah EFI yang memperoleh nilai 3, 20. Berdasarkan nilai tersebut dapat dikatakan bahwa pembentukan Tambrauw sebagai Kabupaten Konservasi akan memperoleh manfaat optimal dari peluang, meski memiliki keterancaman yang dihadapinya. Kondisi ini berarti bahwa faktor ancaman dapat ditutupi melalui optimalisasi faktor-faktor peluang pembentukan kabupaten Konservasi. Dinamika lingkungan eksternal berupa pengembangan potensi wisata, menguatnya kebijakan pengelolaan hutan melalui skema kesatuan Pengelolaan Hutan -Konservasi (KPHKonservasi) serta kabupaten konservasi menjadi destinasi wisata di Papua Barat akan berpotensi meningkatkan manfaat dari pembentukan Tambrauw sebagai kabupaten konservasi serta memperkecil faktor -faktor keterancaman. Lebih lanjut Fatem dan Asem (2014) mengatakan bahwa dua strategi pembentukan
Kabupaten Konservasi dilakukan melalui strategi adaptasi dan strategi optimalisasi. Strategi optimalisasi dilakukan melalui optimalisasi pemanfaatan sumberdaya alam dimana konsep investasi hijau menjadi leading sector. Salah satunya adalah sektor pariwisata di Kabupaten Tambrauw yang sementara dikembangkan. Sementara strategi adaptasi dilakukan melalui integrasi kebijakan Kabupaten Konservasi kedalam dokumen perencanaan daerah yakni RPJMD Kabupaten Tambrauw 2017-2022, Rencana Strategik (Renstra) dan Rencana Kerja (Renja) setiap organisasi perangkat daerah.

Selanjutnya dari hasil analisis nilai faktor internal (3.20) dan eksternal (2.75) tersebut, kemudian dipetakan sesuai tipe masing-masing yaitu strength, weaknesses, opportunities dan threats dalam peta posisi kekuatan internaleksternal dan di peroleh pembentukan Tambrauw sebagai Kabupaten Konservasi.
II

$\mathrm{W}=0.40$
VI

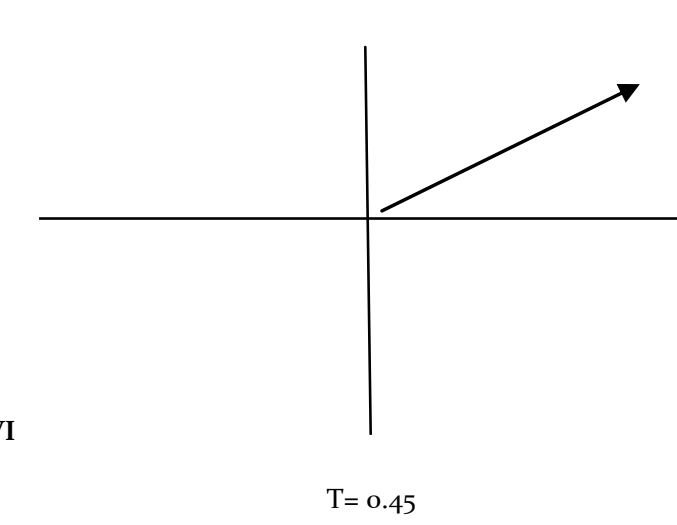

Layak untuk ditetapkan sebagai kabupaten konservasi

III

Gambar 2. Hasil Peta Posisi Kuadran 


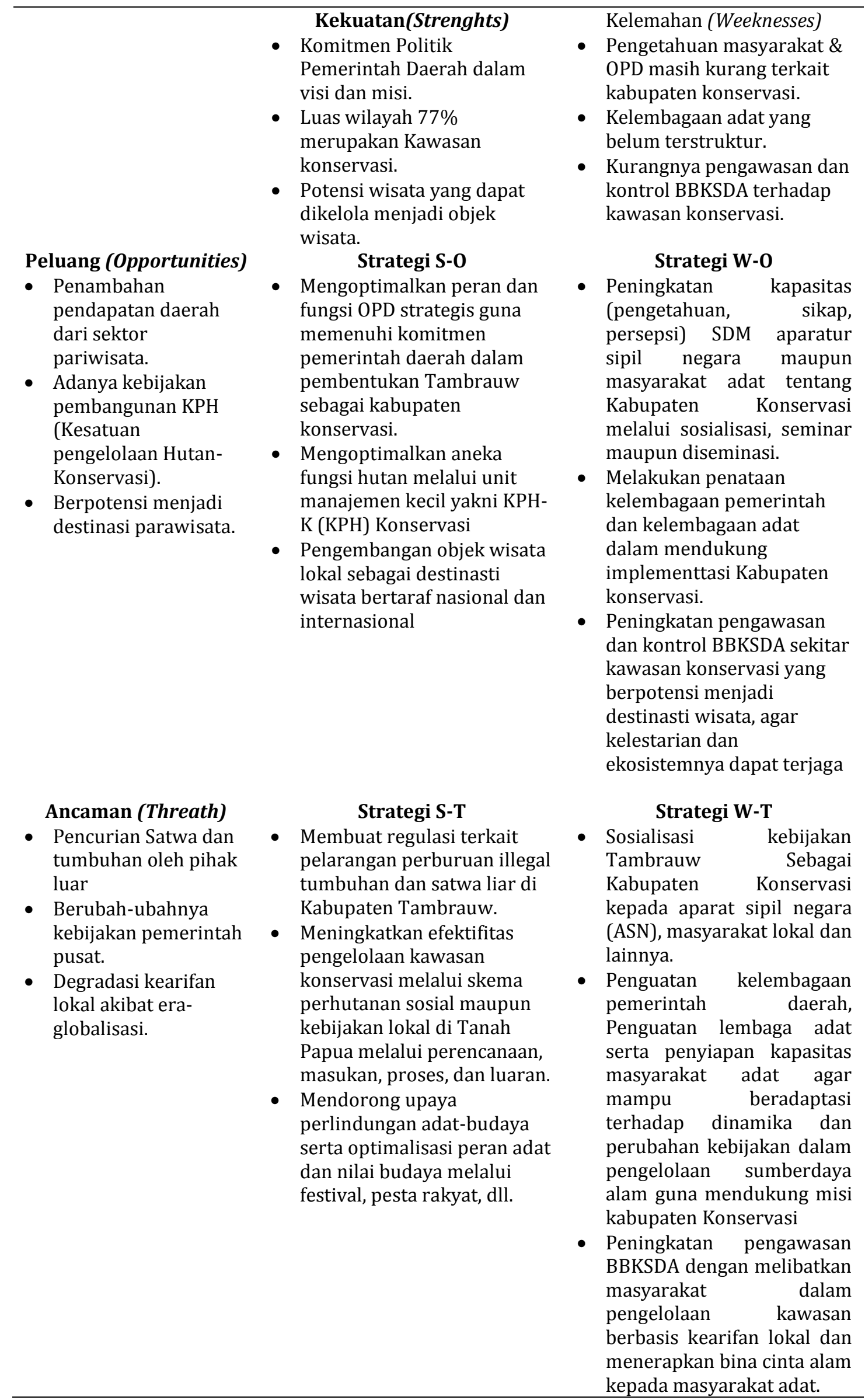

Gambar 3. Matrik SWOT Pengembangan Tambrauw Sebagai Kabupaten Konservasi 
Gambar 2. dengan jelas memperlihatkan bahwa nilai $\mathrm{S}$ dan $\mathrm{O}$ sangat besar dibandingkan $\mathrm{W}$ dan T. Dengan demikian pencanangan dan pembentukan Tambrauw sebagai kabupaten konservasi dapat dilaksanakan dengan melihat strategi dari hasil analisis SWOT tersebut. Khususnya nilai internal dan eksternal terlihat bahwa nilai internal lebih besar dibandingkan dengan nilai eksternal dan berada pada kuadran I. Artinya situasi yang menguntungkan, untuk menjadikan Tambrauw sebagai kabupaten konservasi sehingga dapat memanfaatkan formulasi rumusan strategi SO, WO, ST dan WT. Strategi ini pada prinsipnya saling berkaitan antara faktor-faktor internal dan eksternal dalam mendukung pembentukan Tambrauw sebagai kabupaten konservasi.

\subsection{Analisis SWOT}

Pembentukan Tambrauw sebagai Kabupaten konservasi tentunya memiliki keterkaitan erat dengan dengan factor-faktor pemungkin. Faktor pemungkin ini bersifat lokal dan menjadi pilar utama strategisbagi terbentuknya Kabupaten Konservasi. Untuk itu dalam penelitian ini, dilakukan identifikasi SWOT (Strength, Weakness, Opportunity, Threats). Adapun langkah-langkah analisis SWOT sebagai berikut: Mengidentifikasi faktor-faktor strategis Kabupaten Konservasi, Meingidentifikasi kekuatan (S), Kelemahan (W), Peluang (O), dan ancaman ( $\mathrm{T}$ ) dari hasil pengamatan yang dilakukan. Dari hasil identifikasi, dipilih 12 unsur yang dianggap penting dari setiap komponen SWOT. Selanjutnya untuk menentukan strategi yang akan dijalankan, maka dilakukan dengan membuat matriks gabungan dari keempat komponen SWOT. Dari hasil matriks gabungan, ditentukan strategi dalam kelompok umum (SO, WO, ST, dan WT), yang selanjutnya akan terjabarkan dalam bentuk yang lebih spesifik (Rangkuti, 2005 dalam Aprilia Kukuh et al. 2016).

\subsection{Formulasi Strategi}

Formulasi strategi pembentukan Kabupaten Tambrauw Sebagai Kabupaten Konservasidilakukan menggunakan matriks SWOT. Formulasi strategi adalah langkah penyusunan alternatif strategi pembentukan Kabupaten Konservasi. Tahap ini sering disebut sebagai matching stage. Pada tahap ini dilakukan pencocokan terhadap faktor internal dan eksternal untuk menemukan strategi yang tepat. Matriks SWOT digunakan pada tahap ini. Perumusan strategimenghasilkan empat alternatif, yaitu Strategi Strength-Opportunity (Strategi SO), Strategi Strength -Threath (Strategi ST), Strategi Weakness-Opportunity (Strategi WO), dan Strategi Weakness-Threath (Strategi WT). Hasil perumusan strategi dengan menggunakan Matriks SWOT ditunjukkan pada gambar 2 diatas. Secara rinci formulasi strategi dimaksud djabarkan dibawah ini:

\section{Strategi S-O (Strength and Opportunities)}

a. Mengoptimalkan komitmen politik pemerintah daerah untuk menjadikan Tambrauw sebagai kabupaten konservasi agar dapat menambah pendapatan daerah dengan cara evaluasi program kerja dari OPD terkait. Dinas Pariwisata Kabupaten Tambrauw, Dinas Lingkungan Hidup, Badan Pemberdayan Masyarakat maupun Badan Perencana dan Pembangunan Daerah Tambrauw dapat menginventaris potensi-potensi wisata yang berada di Kabupaten Tambrauw, dan menyusun program untuk dikembangkan sebagai objek daya tarik wisata di Kabupaten Tambrauw. Menurut informan 34, 62 dan 64, dibutuhkan komunikasi, koordinasi dan kerjasama lintas OPD baik program fisik dan non fisik sesuai tugas organisasi perangkat daerah dalam mengembangkan destinasi wisata di Kabupaten Tambrauw. Wisata berbasiskan kelestarian ekologi dan sosial (ekowisata) saat ini semakin luas dikenal sebagai salah satu daya tarik ekonomi yang menguntungkan dan terus dipromosikan secara gencar dalam upaya konservasi hutan hujan tropis (Purwanto, 2014). Promosi wisata dapat dilakukan melalui 3 aspek yang dikenal dengan istilah triple A (Atraksi, Amenitas, and Aksesibilitas). Produk wisata dapat diartikan sebagai segala sesuatu yang dapat dijual sebagai komoditas pariwisata. Atraksi wisata terdiri dari potensi flora, fauna, bentang alam dan atraksi buatan berupa seni dan budaya masyarakat (Muttaqin et a, 2011)

b. Mengoptimalkan luas kawasan konservasi di Kabupaten Tambrauw melalui peluang pembentukan Kesatuan Pengelolaan Hutan (KPH). Berdasarkan SK.783/Menhut-II/2014 luas kawasan Kabupaten Tambrauw 1,199,962 Ha dan 77,039,172 Ha adalah kawasan konservasi jika dipersentasikan sekitar 77-80 $\%$ adalah kawasan konservasi, maka dibutuhkan unit manajemen kecil untuk mengelolanya. Wawancara dengan informan 1 dan 2, terungkap bahwa KPH Konservasi sangat mungkin dibentuk di kabupaten Tambrauw 
dengan pertimbangan potensi luasan areal konservasi. Implementasi KPH sebenarnya sudah sesuai dengan komitmen negara untuk mewujudkan pengelolaan hutan lestari yang telah diatur (UU 41/1999, PP 44/2004, PP 6/2007 jo 3/2008). KPH adalah organisasi yang mewakili entitas kawasan ditingkat lapangan untuk menjamin peningkatan kepastian kawasan dan terselenggaranya keberlanjutan tata kelola kawasan untuk produksi hasil hutan (kayu dan non kayu), penyerapan karbon, ekowisata maupun kesejahteraan masyarakat (Suryandari dan Sulfiani, 2012). Tidak hanya skema KPH-K, namun, pemerintah telah mengeluarkan Permen LHK Nomor 83 tahun 2016 tentang perhutanan sosial dan Permen LHK 43/2017 tentang pemberdayaan masyarakat disekitar kawasan suaka alam dan pelestarian alam. Dengan demikian, ruang bagi pemberdayaan masyarakat adat sebagai bagian dari manajemen kawasan konservasi dalam mendukung Kabupaten konservasi secara perlahan-lahan terbuka lebar melalui hadirnya regulasi dimaksud.

c. Kabupaten Tambrauw memiliki nilai objek wisata yang berpotensi menjadi destinasi wisata. Dengan cakupan 29 distrik dan 216 Kampung, Kabupaten Tambrauw menyimpan potensi objek wisata yang tak kalah menarik. Beberapa site potensi wisata dimaksud antara lain : hamparan ekosistem alang-alang (savanna) membentang luas pada Lembah Kebar mencakup 19.000 ha sekaligus sebagai habitat bermain satwa rusa (Cervus timorensis), sumber air panas alam di Kampung Atai Kebar; Hutan Arboretum Damar Kebar dan Lokasi habitat tanaman rumput penyubur kandungan wanita Banondit (Biophytum peterzianum ), Air Terjun Kampung Siakwa Miyah, Habitat Bermain Burung Cenderawasih di Kampung Weyos, Ases, Miyah, Tabamsereh, Habitat Peneluran Penyu Belimbing (Dermochelys coriaceae) di Taman Pesisir Jee Woomom Distrik Abun, Wisata Religi Pulau Dua (RIPPDA, Tambrauw 2016). Keberadaan obyek ini telah menjadi sasaran dikunjungi oleh sekelompok wisatawan lokal maupun mancanegara setiap bulan. Dengan demikian memiliki arti strategis untuk dikembangkan sebagai destinasi wisata berkelanjutan di Kabupaten Tambrauw.

\section{Strategi W-O (Weaknesses and Opportunities)}

a. Meningkatkan persepsi dan sikap pada aparat organisasi perangkat daerah (OPD) terlebih dahulu terkait kebijakan Kabupaten Konservasi. Meningkatkan pengetahuan dapat dilakukan melalui sosialisasi, seminar dan maupun forum lainnya. Isu konservasi di
Kabupaten Tambrauw cukup trend, sehingga 'mentriger" ruang kerjasama dan dukungan lembaga swadaya masyarakat dan pihak lain cukup banyak di Kabupaten Tambrauw. Kemitraan dan kerjasama ini menjadi peluang untuk meningkatkan pemahaman dasar kebijakan Kabupaten konservasi. Kebijakan mengenai kabupaten konservasi perlu dibangun pada tataran OPD dan masyarakat adat. Adanya seminar maupun forum lainnya guna mencari solusi agar kabupaten konservasi kedepanya dapat berjalan berdasarkan prinsip kabupaten konservasi yang dapat diartikan dalam 3 (tiga) aspek, yaitu: 1) sebagai suatu wilayah kabupaten yang memiliki kesatuan ekosistem serta aktivitaspembangunannya mengadopsi konsep konservasi sumberdaya alam, baik di dalam, maupun di luar kawasan konservasi; 2) pemanfaatan sumberdaya alam mengadopsi prinsip pengelolaan sumberdaya alam secara lestari; 3) melakukan restorasi dan rehabilitasi ekosistem untuk memulihkan fungsi dari ekosistem tersebut, dan untuk memanfaatkan peluang agar dapat menambah pendapatan daerah juga masyarakat sekitar. Upaya pendampingan maupun pelatihan seperti pemanfaatan sumberdaya alam dengan menawarkan potensi wisata, pemanfaatan hasil hutan bukan kayu serta skema lainnya bagi pendapatan daerah dan meningkatkan perekonomian masyarakat perlu didorong untuk memperkecil dikotomi antara ekonomi dan konservasi.

b. Kebijakan pemerintah melalui Kementrian Lingkungan Hidup dan Kehutanan mengeluarkan Undang-Undang No. 41 Tahun 1999, PP. 44 Tahun 2004 dan PP. 6 Tahun 2007 Jo. PP 3 Tahun 2008 tentang pengelolaan hutan ditingkat provinsi, Kabupaten /Kota maupun ditingkat tapak memandatkan bahwa pembentukan wilayah pengelolaan hutan berbarengi dengan kesiapan masyarakat adat sebagai kelompok sosial yang memiliki hak dan akses terhadap hutan (Suharjito, 2017). Menurut informan 2 dan 22, bahwa pembentukan wilayah pengelolaan hutan tingkat Kabupaten/kota maupun tingkat tapak sebagai amanat UU 23/2014, dilaksanakan dengan mempertimbangkan karakteristik lahan, tipe hutan, fungsi hutan, kondisi daerah aliran sungai, sosial budaya, aspirasi, kearifan tradisional, ekonomi, kelembagaan masyarakat setempat termasuk masyarakat hukum adat dan batas administrasi pemerintahan. Dengan demikian, peluang ini perlu di respon dengan mendorong penataan 
dan pembentukan kelembagaan adat masyarakat. Kelembagaan ini dimaksudkan sebagai "unity" dalam memperoleh pengakuan (legitimasi) dan kewenangan untuk mengembangkan bisnis dalam pengelolaan hutan. Terbentuknya kelembagaan adat akan mampu mendorong kelompok-kelompok usaha hutan kelola masyarakat adat yang memiliki rencana kerja jangka panjang, berkelanjutan dan mendorong peningkatan ekonomi sejalan kelestarian ditingkat wilayah adatnya/tapak.

c. Kawasan Konservasi secara aturan menjadi wewenang Balai Besar Konservasi Sumberdaya Alam (BBKSDA) sebagai perpanjangan tangan institusi Kementrian Lingkungan Hidup dan Kehutanan di daerah. Sebagai salah satu unit pelaksana teknis Kementrian Lingkungan Hidup dan Kehutanan, salah satu fungsinya sebagai pengelola kawasan Cagar Alam. Di kabupaten Tambrauw terdapat kawasan Cagar Alam Tambrauw Utara dan Cagar Alam Tambrauw Selatan. Kedua reserve ini sangat strategis menjadi destinasi wisata, sehingga perlu adanya pengawasan dan kontrol oleh BBKSDA dalam upaya pengelolaannya. Mengingat perkembangan pembangunan dan keterbukaan akses jalan kabupaten hingga trans nasional mendorong terjadinya ektraksi illegal pada tumbuhan dan satwa liar. Berdasarkan data lapangan dan terkonfirmasi dari informan masyarakat adat nomor 44,45,53 dan 63, terdapat beberapa oknum masyarakat bahkan aparat keamanan (TNI/POLRI) yang terlibat menjual satwa yang dilindungi berupa Cenderawasih Kuning-Besar (Paradisea apoda) kepada wisatawan lokal yang sering berkunjung di Kabupaten Tambrauw. Motif ekonomi menjadi alasan klasik dibalik transaksi illegal tersebut. Masyarakat menjual satwa langka tersebut agar dapat memenuhi kebutuhan hidup. Fakta ini mengindikasikan bahwa peran dari BBKSDA perlu ditingkatkan dalam mengawal upaya perlindungan dan pelestarian terhadap satwa endemic bahkan menawarkan program alternative bagi masyarakat lokal. Dengan demikian beberapa langkah seperti preemptif, langkah preventif, langkah represif dan langkah pemulihan dapat dilakukan oleh BBKSDA sebagai insititusi yang bertanggunjawab langsung (Wahono, 2016). Langkah-langkah diatas sangat diperlukan agar kedepanya kawasan-kawasan konservasi yang berpotensi sebagai destinasi wisata terjaga kelestarianya. Meskipun demikian, perlu disadari bahwa konflik ekonomi dan program konservasi sering berbenturan. Program kemitraan kehutanan, kemitraan konservasi maupun paket wisata alam berupa bird watching perlu didorong untuk mengatasi masalah diatas serta memberikan insentif bagi masyarakat asli setempat. Zakiyyah et al. (2016) menerangkan bahwa untuk mengubah sikap masyarakat diperlukan dua proses, pertama proses dimana masyarakat menanggapi berbagai isyarat yang mendasar dan heuristik dalam suatu kondisi serta kedua yakni masyarakat menanggapi informasi terhadap sikap yang relevan yang dihasilkan dari suatu kondisi.

\section{Strategi S-T (Strenghts and Threath)}

a. Keberadan kawasan konservasi yang sangat luas dimana hampir 77-80 \% total wilayah administrasi Kabupaten Tambrauw merupakan kawasan konservasi. Hal ini memberi makna bahwa potensi keanekaragaman hayati wilayah ini sangat tinggi. Berdasarkan informasi wawancara pada informan 42, 49, 57 dan 61 di kampung-kampung sampel penelitian mengatakan bahwa sering terjadinya pencurian satwa yang dilindungi seperti burung cenderawasih (Paradisea spp), Rusa (Cervus timorensis) serta tumbuhan seperti anggrek hitam (Ceologyne pandurata) oleh oknum-oknum di luar Kabupaten Tambrauw. Aktivitas ini sangat meresahkan masyarakat adat di Kabupaten Tambrauw, sehingga desakan terus bergulir agar pemerintah Kabupaten Tambrauw menerbitkan regulasi daerah terkait pelarangan perburuan satwa dan tumbuhan illegal diwilayah hukum Kabupaten Tambrauw. Guna memperkuat basis legal regulasi kabupaten atas sumberdaya alam, maka peraturan kampung harus menjadi pijakan pembentukan regulasi dimaksud ditingkat atas. Proses pembentukan peraturan kampung harusnya dilakukan melalui mekanisme musyawarah kampung dan sosialisasi proses pembentukannya. Tugas pemerintah baik kabupaten, distrik dan kampung yakni menfasilitasi mekanisme pembentukan peraturan kampung melalui musyawarah kampung atas keterlibatan masyarakat dan tokoh adat serta mengakomodir hasil musyawarah tersebut menjadi peraturan bupati ataupun Perda yang nantinya akan menjadi payung hukum bagi semua pihak. Kekuatan dan semangat konservasi yang telah ditetapkan di Kabupaten Tambrauw, 
diyakini menjadi modal utama dalam memperkecil terjadinya perburuan illegal tumbuhan dan satwa liar. Ancaman ini dapat tertutupi melalui tersedianya regulasi kabupaten maupun kemitraan Pemerintah Kabupaten Tambrauw bersama TNI-POLRIBBKSDA. Selama proses pengambilan data lapangan, diketahui bahwa pemerintah Kabupaten Tambrauw sedang membangun kerangka kerja dan kesepakatan bersama TNI-POLRI dan BBKSDA guna pencegahan kerusakan hutan, perburuan illegal tumbuhan dan satwa liar di wilayah hukum Kabupaten Tambrauw.

b. Kawasan konservasi di Kabupaten Tambrauw sekitar $80-77 \%$ dari wilayah administrasi pemerintahan. Cakupan ini antara lain; Kawasan Suaka Alam /Kawasan Pelestarian Alam sekitar 61,339 Ha, Hutan Lindung 31,8769 Ha dari luasan Kabupaten Tambrauw Kawasan konservasi memiliki fungsi yang sangat penting yaitu sebagai sebuah sistem penyangga kehidupan. Meski demikian, karakteristik biologis dan kepentingan pengelolaannya yang kompleks menyebabkan selama ini kawasan konservasi belum dikelola secara efektif sehingga mengalami kerusakan secara terus menerus. Nordiansyahet al (2016) mengatakan bahwa evaluasi efektivitas pengelolaan dilakukan dengan melakukan penilaian terhadap empat aspek dalam siklus pengelolaan yaitu: perencanaan, masukan, proses, dan keluaran. Setiap aspek merupakan kumpulan komponen pengelolaan. Sebagaimana dimaksud dari aspek-aspek tersebut sangat berperan penting guna dalam pengambilan keputusan, sehingga perlu mendapat pertimbangan khusus. Keberpihakan Negara melalui hadirnya program perhutanan sosial maupun reforma agraria menjadi pintu masuk bagi pemberdayaan masyarakat adat. Di Tanah Papua, tanah, air, sungai, hutan dan lahan telah menjadi bagian dari kepemilikan masyarakat adat. Hal ini berarti bahwa, ruang kelola masyarakat adat perlu diprioritaskan dalam mengoptimalisasikan pengelolaan kawasan konservasi. Di Kabupaten Tambrauw terdapat 5 suku besar yang memiliki wilayah adat. Selama proses penelitian, diketahui bahwa 5 (lima) wilayah adat tersebut telah terpetakan secara indikatif. Menurut informan 31, 32, 33, 34 dan 35, meski masih bersifat indikasi, namun informasi awal berupa jumlah marga, keret, tempat penting masyarakat adat telah terpetakan. Dengan demikian akan menjadi kekuatan dalam mendukung program konservasi jika sinergitas bersama kelompok adat tersebut terus dibangun. Kerjasama dan komunikasi yang efektif antara masyarakat adat, pengelola kawasan bersama pemerintah daerah akan menjadi 'area' yang mendukung pengelolaan kawasan konservasi karena kesamaan dan keseimbangan kepentingan (Marina dan Dharmawan, 2011).

c. Seiring berjalannya waktu, eksistensi kearifan lokal dan budaya di Kabupaten Tambrauw setidaknya tengah berada pada kondisi yang mengarah pada kelunturan atau degradasi sosial-budaya. Penetrasi global yang tidak mengenal dimensi ruang dan waktu dapat dikatakan telah membawa cerita baru dalam perkembangan tatanan budaya di Kabupaten Tambrauw, diantaranya pendidikan adat yang dalam bahasa lokal di sebut (Wuon Woffle). Pendidikan ini bertujuan mengajarkan pemahaman adat, alam, penghormatan terhadap alam, kepercayaan, budaya resiprositas dan kerjasama. Sebagaimana penjelasan informan 38 dan 39bahwa, orang yang bersekolah adat disebut "Wuon"yang akan berada di hutan selama 6-12 bulan. Hutan, alam, air, sungai, gunung dan batu maupun tumbuhan dan satwa diposisikan sebagai leluhur yang harus dihormati. Sehingga penting untuk dijaga dan dihargai. Budaya ini telah membentuk tatanan kehidupan orang Tambrauw sehingga dijadikan sebagai kearifaan local. Kearifan lokal dimaknai sebagai pandangan hidup dan ilmu pengetahuan serta berbagai strategi kehidupan yang berwujud aktivitas yang dilakukan oleh masyarakat lokal dalam menjawab berbagai masalah dalam pemenuhan kebutuhan mereka (Fajarini, 2014; Ungirwalu et al, 2016). Dalam komunitas masyarakat adat, kearifaan tradisional diwujudkan dalam bentuk seperangkat aturan, pengetahuan, keterampilan serta tata nilai dan etika yang mengatur tatanan sosial komunitas yang terus hidup dan berkembang dari generasi ke generasi (Thamrin 2013) dalam (Lake et al. 2017). Berdasarkan infomasi yang diambil dari responden masyarakat adat, diketahui bahwa sekolah adat (wouon woffle), mengalami ancaman degradasi globalisasi serta beberapa tokoh agama menganggap masih erat dengan animisme. Hal ini berbanding terbalik dalam konteks konservasi dan ekowisata. Dalam konteks konservasi dan ekowisata, kearifan lokal bukan saja menjadi alat dalam menjaga kelestarian hidup, melainkan juga sebagai platform dalam memperkuat keharmonisan 
ekologis serta keunikan sumberdaya untuk menstimulasi keberlanjutan kearifan lokal itu sendiri (Fatem et al, 2014). Selain itu, berbagai kearifaan lokal yang kian terdegradasi atau sudah tidak dikenal, akan terevitalisasi kembali seiring meluasnya permintaan atraksi ekowisata. Salah satu solusi untuk mengatasi ancaman seperti ini melalui pembentukan regulasi bagi upaya perlindungan kearifaan lokal masyarakat Tambrauw. Unsur estetika dan seni yang terungkap diatas dapat dijadikan sebagai obyek wisata minat khusus. Pemerintah Daerah dapat mendorong terbentuknya kelompok sadar wisata yang dibina langsung dalam menyelenggarakan paket wisata sesuai karakteristik unggulan tiap kampung dan distrik wilayah Tambrauw. Mereka dapat teragregasi melalui kelompok pemandu wisata maupun masyarakat adat yang menyiapkan dan menawarkan layanan wisata alam baik minat khusus maupun minat umum. Program festival seni dan budaya adat Tambrauw penting untuk lakukan setiap tahun sebagai ajang promosi adat, budaya dan seni guna peningkatan ekonomi daerah.

\section{Strategi W-T (Weaknesses and Threath)}

a. Kabupaten Tambrauw dicanangkan sebagai kabupaten konservasi berdasarkan visi dan misi dari Bupati Kabupaten Tambrauw pada butir ke lima "Menjaga lingkungan dengan menetapkan Tambrauw Sebagai Kabupaten Konservasi". Tak heran jika komitmen pemerintah daerah ingin menjadikan Kabupaten Tambrauw sebagai kabupaten konservasi dikarenakan fungsi hutan Kabupaten Tambrauw hampir mencapai $80 \%$ dari total wilayah administrai pemerintahan. Misi kabupaten konservasi merupakan misi yang tidak mudah terimplementasikan, karena menyangkut perubahan tatakelola sebagaimana mana disampaikan oleh informan 7 dalam wawancara penelitian. Perubahan tatakelola dapat dilakukan melalui proses penataan kembali (re-inventing). Proses penataan kembali hanya bisa dilakukan jika organisasi penggerak yakni aparat organisasi perangkat daerah dan masyarakat memiliki kapasitas dalam menterjemahkan misi dari pemerintah Kabupaten Tambrauw dimaksud. Dengan demikian penguatan kapasitas menjadi penting dalam mengawal pembentukan Kabupaten Konservasi. Nitiwijaya (2015) mentakan bahwa tugas, pokok dan fungsi dinas dilihat dari persepsi birokrasi dimana peran OPD sangat dibutuhkan dengan beberapa aspek: sikap terhadap kebijakan kabupaten konservasi, pemahaman yang benar terhadap konsep kabupaten konservasi, peran aktif OPD terhadap imlementasi kabupaten konservasi danfrekuensi program dukungan OPD bagi kabupaten konservasi. Hasil diskusi selama pengambilan data, dijumpai bahwa misi kabupaten konservasi pada tataran OPD di Kabupaten Tambrauw masih kurang dipahami. Umumnya misi Kabupaten konservasi hanya dipahami pada tataran top level, sebaliknya supporting sistem belum memahami kebijakan dimaksud. Dengan demikian peningkatan pemahaman kepada OPD di Kabupaten Tambrauw mutlak dilakukan. Selanjutnya, pada level masyarakat adat pun demikian, kebijakan Kabupaten Konservasi belum dipahami baik, sehingga membutuhkan proses. Padahal masyarakat adat menjadi pilar utama dari pembangunan konservasi melalui kearifaan lokal mereka. Konservasi modern harus bisa disinergikan dengan kearifaan lokal, sehingga saling mendukung dalam upaya konservasi. Hal ini sejalan dengan Escobar, 1996; Brosius 1997; Li 2002 dan Darmanto 2011 bahwa wacana konservasi bukanlah wacana netral dan muncul dari ruang hampa. Wacana konservasi sangat terkait erat dengan aspek kekuasaan, produksi dan makna baik tingkat global dan lokal. Setiap aktor akan mendefinisikan konservasi pada tataran yang berbeda-beda. Artikulasi ini mendorong terjadi nya ruang relasi sosial antar para aktor dan powernya (Prabowo et al., 2016; Maryudi \&Sahide, 2017)

b. Peran kelembagaan adat dalam pengelola kawasan konservasi sangat vital. Karena implementasi Kabupaten konservasi membutuhkan partisipasi dan gerakan semua elemen masyarakat adat. Selain kelembagaan adat, kelembagaan pemerintah pun perlu dibenahi dalam mewujudkan implementasi Kabupaten Konservasi. Komitmen politik Kabupaten Konservasi mensyaratkan penataan tatakelola baik kelembagaan adat maupun kelembagaan pemerintah. Kelembagaan adat perlu dilakukan agar masyarakat memiliki ruang dan organisasi untuk berpartisipasi dalam mendukung kebijakan kabupaten konservasi. Kelembagan pemerintah dapat berupa sistem aliran informasi dan perencanaan pembangunan, regulasi maupun sumberdaya manusia. Sementara kelembagaan adat dapat berupa kearifaan lokal, sanksi, aturan adat serta organisasi adat itu sendiri. Penelitian ini 
menemukan bahwa kelembagaan adat di kabupaten Tambrauw cukup baik dalam mengawal aspirasi dan kebutuhan masyaraat lokal. Hasil wawancara bersama pimpinan Lembaga Swadaya Masyarakat (LSM) lokal di Kabupaten Tambrauw seperti Yayasan Akawuon dan Yayasan Marwasnath, menunjukkan bahwa penyelesaian persoalan masyarakat adat berkaitan dengan tanah, hutan, air dan manusia menjadi fokus yang secara bertahap dilakukan oleh masyarakat adat. Kedua lembaga ini merupakan anakanak muda yang terdorong kerja -kerja pemetaan suku, marga dan tempat penting, potensi dan nilai sumberdaya alam diwilayah adat di kabupaten Tambrauw. Mereka telah mendampingi pelaksanaan Musyawarah Adat (MUSDAT) pada suku Mpur dan Abun dalam menyelesaikan batas-batas wilayah adat. Ke depannya, terdapat beberapa suku yang telah menjadi agenda kerja mereka dalam melakukan musyawarah adat baik suku Miyah, Ireres maupun suku Mooi Kelim. Agregasi dari kerja-kerja pemetaan masyarakat adat ini akan bermuara pada Perda Kabupaten Konservasi dan Perda Masyarakat adat maupun kelembagaan adat suku yang ada di kabupaten Tambrauw. Peran pemerintah dapat dilakukan melalui fasilitasi proses musyawarah adat (MUSDAT). Hasil musyawarah adat akan menjadi acuan bagi pembentukan produk hukum daerah di Kabupaten Tambrauw. Dengan mendorong penataan kembali dan legitimasi kelembagaan adat maupun kelembagaan pemerintah, maka secara perlahan-lahan masyarakat adat maupun pemerintah daerah akan memahami peran dan posisinya dalam menyikapi dinamika pembangunan dan perubahan kebijakan, khususnya konservasi sumberdaya alam dan lingkungan (Pudyatmoko eta al, 2018).

c. Salah satunya tugas UPT Kementrian Lingkungan Hidup dan Kehutanan di daerah melalui BBKSDA yakni penataan kawasan dan penyusunan rencana pengelolaan Cagar Alam, Suaka Margasatwa, Taman Wisata Alam, serta pelaksanaan perlindungan dan pengamanannya. Berdasarkan informasi yang diambil dari tiap kampung sampel penelitian, diketahui bahwa aspek pengawasan dan pengamanan kawasan di Kabupaten Tambrauw sangat minim bahkan jarang dilaksanakan. Tingginya kejadian perburuan liar, pencurian satwa dan tumbuhan memberikan makna bahwa fungsi perencanaan dan pengawasan BBKSDA masih sangat kurang (Asem et al 2011). Kondisi ini secara tidak langsung mendorong kearifan lokal masyarakat perlahan mulai hilang. Budaya masyarakat yang dulunya berburu menggunakan jerat, tombak dan panah serta bantuan anjing berburu mulai kurang. Masyarakat lebih memilih berburu menggunakan senapan angin, karena dianggap akan mendapat hewan buruan semakin cepat serta jumlah yang banyak. Penggunaan senapan angin ini tentunya bukan tradisi masyarakat sekitar tetapi tradisi berburu moderen, yang dibawa oleh oknum-oknum luar yang masuk dalam tatatan kehidupan masyarakat sehingga mempengaruhi masyarakat untuk mengikutinya. Hal ini tentunya membawa dampak buruk terhadap keterancaman tumbuhan dan satwa. Dengan demikian dibutuhkan perencanaan dan pengawasan dari aktor BBKSDA lebih ekstra ketat untuk meminimalkan kelemahan ini. Salahsatu melalui pembangunan pos-pos jaga dan menambah satuan polisi kehutanan (POLHUT) sekitar kawasan konservasi. Selanjutnya mendorong program strategis lainnya seperti peningkatan bina cinta alam, penyuluhan konservasi sumber daya alam dan ekosistemnya. Menurut informan 40, pemberdayaan masyarakat dalam dan sekitar kawasan konservasi berbasis kearifaan lokal seperti pembentukan kampung adat, karya seni dan budaya, penyediaan sanggar ukiran dan anyaman dapat berperan mencegah degradasi pengetahuan dan kearifaan lokal serta pergeseran budaya dalam berburu dan meramu sumberdaya alam maupun kesenian.

\section{Kesimpulan}

Berdasarkan hasil penelitian mengggunakan analisis SWOT, diketahui bahwa Komitmen politik Tambrauw sebagai Kabupaten konservasi dapat dilakukan melalui proses deklarasi dan implementasi. Hal ini ditunjukkan melalui nilai S dan $\mathrm{O}$ sangat besar dibandingkan $\mathrm{W}$ dan $\mathrm{T}$ dan berada pada posisi kuadaran I. Artinya bahwa situasi yang menguntungkan, untuk menjadikan Tambrauw sebagai kabupaten konservasi. Secara internal pembentukan Tambrauw sebagai Kabupaten Konservasi memiliki kekuatan besar. Kekuatan ini ditunjukkan melalui nilai Evaluasi faktor internal sebesar 3.20. Sebaliknya kelemahan pada faktor internal seperti rendahnya pengetahuan OPD dan Masyarakat terkait kebijakan Kabupaten Konservasi, kelembagaan adat belum tertata baik serta minimnya fungsi kontrol oleh BBKSDA terhadap kawasan konservasi akan tertutupi melalui peluang yang akan dikembangkan. 
Sementara hasil analisis faktor eksternal pembentukan Kabupaten Konservasi, diketahui memiliki nilai 2.75 .

Berdasarkan nilai tersebut dapat dikatakan bahwa pembentukan Tambrauw sebagai Kabupaten Konservasi akan memperoleh manfaat optimal dari peluang, meski memiliki keterancaman yang dihadapinya. Keterancman tersebut dapat diperkecil melalui 4 pilihan strategi. Pilihan strategi yang dimaksud antara lain: 1) Strategi S-O (Strength and Opportunities). Dilakukan dengan optimalisasi komitmen politik pemerintah daerah melalui peningkatan pengelolaan potensi daerah; optimalisasi luas kawasan konservasi di Kabupaten Tambrauw; pengenjotan potensi ekowisata Kabupaten Tambrauw. 2) Strategi W0 (Weaknesses and Opportunities). Strategi ini dilakukan melalui: Peningkatan kapasitas OPD

\section{DAFTAR PUSTAKA}

Actor-Centred Power (ACP): The importance of understanding the effect of changes in polity for the measurement of power dynamics over time. Forest Policy and Economics, 62, 184186.doi:

http://doi.org/10.1016/j.forpol.2015.10.006.

Angi, E.M., 2005. Kebijakan Pemerintah Pusat di Bidang Konservasi dari Perspektif Daerah dan Masyarakat. Center for International Forestry Research. Jakarta.

Anonim, 2016. Peraturan Menteri Lingkungan Hidup dan Kehutanan Nomor 83 tahun 2016 Tentang Perhutanan Sosial. Kantor Menteri Negara Sekretaris Negara Republik Indonesia. Jakarta.

Anonim, 2017. Peraturan Menteri Lingkungan Hidup dan Kehutanan Nomor 43 tahun 2017 Tentang Perhutanan Sosial. Kantor Menteri Negara Sekretaris Negara Republik Indonesia. Jakarta.

Asem, G., Kahisiuw P., Fatem, S.M., Runtuboy, Y., Marwa, J., 2011.Prospect of Tambrauw as Conservation Regency in West Papua (A Preliminary Analysis). In: M. Taufik Fauzi, Komang Damar Jaya, Hoi Sen Yong, Miko Krisbaucm, M. Sarjan, Lestari Ujianto, Siti Latifa, Baiq Dewi Krisdayanti, editor. Siginificance of Climate Change on Biodiversity in Sustaining the Globe. Proceeding of the $2^{\text {nd }}$ International Conference on Biodiversity". UniversitasMataram, Mataram, 2-4 July 2013.

Asem, G., Fatem, S., 2017.Integrasi Isu Masyarakat Adat dan Konservasi ke dalam dan Masyaraat adat tentang kebijakan Kabupaten Konservasi; Penataan kembali kelembagaan pemerintah dan kelembagaan adat maupun pengembangan ekonomi alternative dikawasan konservasi. 3) Strategi S-T (Strenghts and Threath). Pilihan strategi ini dilakukan melalui tersedianya regulasi tentang pelarangan perburuan illegal tumbuhan dan satwa di Kabupaten Tambrauw; Keterlibatan penuh masyarakat dalam manajemen kawasan konservasi, meregulasi kearifaan lokal yang ada dikabupaten Tambrauw. 4) Strategi W-T (Weaknesses and Threath). Strategi ini dilakukan melalui sosialiasi, diseminasi maupun advokasi pada tingkatan pemerintah Kabupaten maupun masyarakat adat; penataan kembali kelembagaan adat lokal serta optimalisasi peran Balai Konservasi Sumberdaya Alam Papua Barat.

Tata Kelola Pemerintah melalui Kabupaten Konservasi. Materi dalam Seminar Nasional PKMRI Provinsi Papua Barat. 22 Juni 2017

Avenzora, R., Harnios, A.,2017. Khazanah KearifanLokal dalam Memperkuat Konservasi dan Ekowisata: Studi Kasus Masyarakat Adat Dawan di Kabupaten Timor Tengah Utara. Media Konservasi Vol. 22 No. 3 Desember 2017: 213-219.

Bappeda Tambrauw, 2011. Rencana Tata Ruang Wilayah Kabupaten Tambrauw.

Bappeda Tambrauw, 2014. Rencana Tata Ruang Wilayah Revisi Kabupaten Tambrauw.

[BKSDA PB] Balai Konservasi SumberdayaAlam Papua Barat, 2013. Buku Informasi Kawasan Konservasi di Papua Barat.

Brosius, J.P., 1997. Green dots, pink heart. Displacing politic from the Malasyan Rain Forest. American Anthropologis 101: 36-57.

Darmanto, 2014. Konservasi Global, Taman Nasional dan Praktek Lokal di Pulau Siberut, Sumatera Barat. Jurnal Ilmu Kehutanan. Volume V. No 1. Januari -Maret 2014.

Dinas Pariwisata Tambrauw. 2016. Rencana Induk Pembangunan Pariwisata Kabupaten Tambrauw.

Dwijayati, A.K., Suprapto, D., Rudiyanti, S., 2016. Identifikasi Potensi Dan Strategi Pengembangan Ekowisata Pada Kawasan Konservasi Hutan Mangrove Desa Pasar Banggi Kabupaten Remban. Diponegoro Journal Of Maquares Volume 5, Nomor 4, Tahun 2016, Halaman: 328-336

Escobar, A., 1998. Whose knowledge, whose nature? Biodiversity, conservation, and the 
political ecology of social movements. Journal of Political Ecology, 5(1), pp.53-82

Fatem, S., Asem, G., 2015. 'Kabupaten konservasi sebagai political action pemerintah daerah dalam mendukung konservasi sumberdaya alam hayati: Studi kasus Kabupaten Tambrauw, Papua Barat' dalam PROS SEM NAS MASY BIODIV INDON. Volume 1, Nomor 5, September 2015. Hlm. 1403-1410. Volume 1, DOI: $10.13057 / \mathrm{psnmbi} / \mathrm{m} 0105 \mathrm{xx}$.

Jepson, P., Whittaker, R.J., 2002. Histories of Protected Area; Internationalization of Conservationist Values and their Adoption in the Netherlands Indies (Indonesia)". Environment and History 8:129-172.

Kartika, S. N., Mashal, A. J., Beehler, B.M., 2007. Seri Ekologi Indonesia jilid IV: Ekologi Papua Yayasan Obor Indonesia. Jakarta.

MacKinnon, J.K. et al., 1993. Pengelolaan kawasan yang dilindungi di daerah tropika, Yogyakarta: GadjahMada University Press.

Marina, I., Dharmawan, A.H., 2011. Analisis Konflik Sumberdaya Hutan di Kawasan Konservasi. Sodality-Jurnal Transdisipilin Sosiologi, Komunikasi dan Ekologi Manusia. ISSN: 1978-4333, Volume 05, No. 01April 2011

Maryudi, A., Sahide, M.A.K., 2017. Research trend: Power analyses in polycentric and multilevel forest governance. Forest Policy and Economics, 81, pp.65-68.

Muttaqin, T., Purwanto, R. H., Rufiqo, S. N., 2011. Kajian potensi dan strategi pengembangan ekowisata di cagar alam Pulau Sempu Kabupaten Malang Provinsi Jawa Timur. http://ejounrnal.ac.id/index.php/gamma/art icle/view/1433

Nitiwijaya, Y. S., 2015. Persepsi birokrat terhadap pemberdayaan ekonomi berbasis kelestarian lingkungan di Kabupaten Kuningan. Jurnal Agrijati 28 No, 1 April 2015.

Nordiansyah, H., Ismail, Ismail, B., 2016. Penilaian Efektivitas Pengelolaan Kawasan Konservasi Di Kawasan Cagar Alam Padang Luway Kabupaten Kutai Barat. Jurnal AGIRIFOR Volume XV Nomor 1, Maret 1 2016.

Petocz, R.G., 1989. Konservasi Alam dan Pembangunan di Irian Jaya. Grafiti press. Jakarta.

Prabowo, D., Maryudi, A., Imron, M. A., Senawi, 2016. Enhancing the application of Krott et al.'s (2014).

Pudyatmoko, S., Budiman, A., Kristiansen, S.,2018. Towards sustainable coexistence: People and wild mammals in Baluran National Park, Indonesia. Forest Policy and Economics, 90, pp.151-159.
Purwanto, S., Lailan, S., Gunawan, A., 2014. Kajian Potensi dan Daya Dukung Taman Wisata Alam Bukit Kelam untuk Strategi Pengembangan Ekowisata. Jurnal Pengelolaan Sumberdaya Alam dan Lingkungan Vol. 4 No. 2 (Desember 2014): 119-12.

Rangkuti, F., 1997. Teknik Membedah Kasus Bisnis Analisis SWOT. PT Gramedia Pustaka Utama, Anggota IKAPI. Jakarta.

Setiawan, A., Alikodra, H., 2001. Tinjauan Terhadap Pembangunan Sistem Kawasan Konservasi di Indonesia. Media Konservasi Vol. VII, No.2 Juni 2001. Hal 39-46.

Soemarwoto, O., $2004 . \quad$ Ekologi, LingkunganHidupdan Pembangunan. Djambatan, Jakarta.

Suharjito, D., 2017. Kesatuan Pengelolaan Hutan (KPH) Kebijakan, Implementasi dan Masa Depan. Multistakeholder Forestry Programme 3 (MFP3) dan Dewan Kehutanan (DKN).

Sumedi, N., Simon, H., Djuwantoko., 2012. Strategi pengelolaan pegunungan Jawa: Studi kasus Pegunungan Dieng Jawa Tengah, Indonesia. Jurnal Penelitian Kehutanan Wallacea Vol.1 No.1, Agustus 2012: 36 - 4.

Suryandari, E.Y., Sylviani, 2012. Kajian Implementasi Kebijakan Organisasi Kesatuan Pengelolaan Hutan (KPH) Di Daerah (Studi Kasus KPH Banjar, Kalimantan Selatan Dan KPH Lalan Mangsang Mendis, Sumatera Selatan). Vol. 996.2. Agustus 2012: 114-130.

Undang-Undang RI No. 41 Tahun 1999 tentang Kehutanan. Kantor Menteri Negara Sekretaris Negara Republik Indonesia. Jakarta. 4 Maret 1999.

Ungirwalu A., Awang SA., Maryudi A., Suryanto, P., 2016. Pengelolaan Adaptif Pemanfaatan Buah Hitam (Haplolobus monticola Blumea) EtnisWandamen-Papua (Adaptive Management Utilization of Black Fruit (Haplolobus monticola Blumea) Ethnic Wandamen-Papua. J. Manusia dan Lingkungan, Vol. 23, No.2, Juli 2016: 266-275

Wahono, R., 2016. Peran Balai Konservasi SumberDaya Alam Daerah Istimewa Yogyakarta (BBKSDA Daerah Istimewa Jogjakarta) dalam pengendalian terhadap perdagangan satwa liar yang dilindungi.

Wikramanayake, E., Dinerstein, E., Loucks, C., Olson, D., Morrison, J., Lamoreux, J., McKnight, M., Hedao, P., 2001. Terrestrial ecoregions of the Indo-Pacific: A conservation assessment. Washington (DC): Island Press

Wiratno, C., Indiroyo, S., Daru, K.,2004. Berkaca di Cermin Retak. Refleksi Konservasi dan Implikasi bagi Pengelolaan Taman Nasional. 
Jakarta: Forest Press, The Gibbon Foundation Indonesia, DepartemenKehutanan, PILI-NGO Movement.

Zakiyyaha, Ervizal, A.M., Zuhud, Sumardjoc, 2016. Sikap masyarakat dan konservasi kasus stimulus pakis sayur di Desa Gunung Bunder II, Kecamatan Pamijahan, Bogor Jurnal Pengelolaan Sumberdaya Alam dan Lingkungan Vol. 6 No. 1 (Juli 2016): 71-76 
Lampiran 1. Informan Dalam Penelitian

\begin{tabular}{|c|c|c|c|}
\hline $\begin{array}{c}\text { Kode } \\
\text { Informan }\end{array}$ & PEKERJAAN & Institusi & ALAMAT \\
\hline 1 & PNS & $\begin{array}{l}\text { Fakultas Kehutanan } \\
\text { Unipa }\end{array}$ & Univeritas Papua Manokwari \\
\hline 2 & PNS & BBKSDA Papua Barat & BBKSDA Papua Barat-Sorong \\
\hline 3 & PNS & $\begin{array}{l}\text { Dinas Kehutanan } \\
\text { Provinsi Papua Barat }\end{array}$ & $\begin{array}{l}\text { Dinas Kehutanan Provinsi Papua Barat } \\
\text {,Manokwari }\end{array}$ \\
\hline 4 & PNS & $\begin{array}{l}\text { Bidang Data dan } \\
\text { Pelaporan, Dinas } \\
\text { Kehutanan Papua Barat }\end{array}$ & $\begin{array}{l}\text { Dinas Kehutanan Provinsi Papua } \\
\text { Barat, Manokwari }\end{array}$ \\
\hline 5 & PNS & Bappeda Papua Barat & Bappeda Papua Barat \\
\hline 6 & PNS & $\begin{array}{l}\text { Dinas Lingkungan Hidup } \\
\text { Papua Barat }\end{array}$ & $\begin{array}{l}\text { Dinas Lingkungan Hidup Papua Barat, } \\
\text { Manokwari }\end{array}$ \\
\hline 7 & & $\begin{array}{l}\text { Pemerintahan Kabupaten } \\
\text { Tambrauw }\end{array}$ & Sausapor - Tambrauw \\
\hline 8 & PNS & $\begin{array}{l}\text { Dinas Pertanian Kab } \\
\text { Tambrauw }\end{array}$ & Sausapor - Tambrauw \\
\hline 9 & & $\begin{array}{l}\text { Perlindungan Tanaman } \\
\text { Dinas Pertanian } \\
\text { Tambrauw }\end{array}$ & Sausapor - Tambrauw \\
\hline 10 & PNS & $\begin{array}{l}\text { Pariwisata dan } \\
\text { Kebudayaan Tambrauw }\end{array}$ & Sausapor - Tambrauw \\
\hline 11 & PNS & $\begin{array}{l}\text { Dinas Lingkungan Hidup } \\
\text { Tambrauw }\end{array}$ & Sausapor - Tambrauw \\
\hline 12 & PNS & $\begin{array}{l}\text { Lingkungan Hidup } \\
\text { Tambrauw }\end{array}$ & Sausapor - Tambrauw \\
\hline 13 & PNS & $\begin{array}{l}\text { Dinas Lingkungan Hidup } \\
\text { Tambrauw }\end{array}$ & Sausapor - Tambrauw \\
\hline 14 & PNS & Dinas Pekerjaan Umum & Sausapor - Tambrauw \\
\hline 15 & PNS & Pekerjaan Umum & Sausapor - Tambrauw \\
\hline 16 & PNS & Bappeda Tambrauw & Sausapor - Tambrauw \\
\hline 17 & PNS & $\begin{array}{l}\text { Perencanaan Bappeda } \\
\text { Tambrauw }\end{array}$ & Sausapor - Tambrauw \\
\hline 18 & PNS & Bappeda Tambrauw & Sausapor - Tambrauw \\
\hline 19 & PNS & $\begin{array}{l}\text { Penanaman Modal dan } \\
\text { Perijinan Satu Pintu }\end{array}$ & Sausapor - Tambrauw \\
\hline 20 & PNS & $\begin{array}{l}\text { Dinas Penanaman Modal } \\
\text { dan Perijinan Satu Pintu }\end{array}$ & Sausapor - Tambrauw \\
\hline 21 & PNS & DKP Tambrauw & Sausapor - Tambrauw \\
\hline 22 & PNS & $\begin{array}{l}\text { CDK Wilayah } 10 \\
\text { Tambrauw }\end{array}$ & Sausapor - Tambrauw \\
\hline 23 & PNS & $\begin{array}{l}\text { Pemerintahan Kabupaten } \\
\text { Tambrauw }\end{array}$ & Sausapor - Tambrauw \\
\hline 24 & PNS & $\begin{array}{l}\text { Dinas Kebudayaan, } \\
\text { Pemuda, dan Pariwisata } \\
\text { Tambrauw }\end{array}$ & Sausapor - Tambrauw \\
\hline 25 & PNS & DLH Tambrauw & Sausapor - Tambrauw \\
\hline 26 & PNS & $\begin{array}{l}\text { Dinas Pariwisata, } \\
\text { Kebudayaan, Pemuda, } \\
\text { dan Pariwisata } \\
\text { Tambrauw }\end{array}$ & Sausapor - Tambrauw \\
\hline 27 & PNS & $\begin{array}{l}\text { Dinas Kebudayaan, } \\
\text { Pemuda, dan Pariwisata } \\
\text { Tambrauw }\end{array}$ & Sausapor - Tambrauw \\
\hline 28 & PNS & DLH Tambrauw & Sausapor - Tambrauw \\
\hline 29 & PNS & CDK Wilayah 10 & Sausapor - Tambrauw \\
\hline
\end{tabular}




\begin{tabular}{|c|c|c|c|}
\hline $\begin{array}{c}\text { Kode } \\
\text { Informan }\end{array}$ & PEKERJAAN & Institusi & ALAMAT \\
\hline & & Tambrauw & \\
\hline 30 & PNS & $\begin{array}{l}\text { Dinas Kebudayaan, } \\
\text { Pemuda, dan Pariwisata } \\
\text { Tambrauw }\end{array}$ & Sausapor - Tambrauw \\
\hline & \multicolumn{3}{|c|}{30 Orang Informan- PNS } \\
\hline 31 & Swasta & $\begin{array}{l}\text { Program Samdhana } \\
\text { Institute untuk Papua }\end{array}$ & Sausapor - Tambrauw \\
\hline 32 & Swasta & Program WWF Sausapor & Sausapor - Tambrauw \\
\hline 33 & Swasta & Epistema Institute & Sausapor - Tambrauw \\
\hline 34 & Swasta & Yayasan Paradisea & Sausapor - Tambrauw \\
\hline 35 & Swasta & Yayasan Akawuon & Sausapor - Tambrauw \\
\hline \multirow[t]{2}{*}{36} & Swasta & Yayasan Marwasnath & Sausapor - Tambrauw \\
\hline & \multicolumn{3}{|c|}{6 Orang Informan- LSM } \\
\hline 37 & Swasta & Masyarakat & Sausapor - Tambrauw \\
\hline 38 & Swasta & Suku Miyah & Kampung Siekwa Distrik Miyah \\
\hline 39 & Swasta & Suku Abun & Distrik Kwoor \\
\hline 40 & Petani & Suku Mpur & Distrik Kebar \\
\hline 41 & Petani & Suku Ireres & Distrik Ireres \\
\hline 42 & Petani & Kampung Meinad & Kampung Meinad Distrik Ireres \\
\hline 43 & Petani & Masyarakat & Kampung Meinad Distrik Ireres \\
\hline 44 & Petani & Masyarakat & Kampung Meinad Distrik Ireres \\
\hline 45 & Petani & Kampung Meis & Kampung Meis Distrik Ireres \\
\hline 46 & Petani & Masyarakat & Kampung Meis Distrik Ireres \\
\hline 47 & Petani & Aparat Kampung & Kampung Wasanggon Distrik Kebar \\
\hline 48 & Petani & Baperkam & Kampung Wasanggon Distrik Kebar \\
\hline 49 & Pelayan Gereja & Masyarakat & Kampung Jafai Distrik Kebar \\
\hline 50 & Petani & Masyarakat & Kampung Jafai Distrik Kebar \\
\hline 51 & Petani & Masyarakat & $\begin{array}{l}\text { Kampung Ataf Mafat Distrik Wilhem } \\
\text { Roumbouts }\end{array}$ \\
\hline 52 & Petani/IRT & Masyarakat & $\begin{array}{l}\text { Kampung Ataf Mafat Distrik Wilhem } \\
\text { Roumbouts }\end{array}$ \\
\hline 53 & Aparat Kampung & Kepala Kampung & Kampung Emaus Distrik Sausapor \\
\hline 54 & Aparat Kampung & Kepala Kampung & Kampung Donan Distrik Sausapor \\
\hline 55 & Petani & Masyarakat & Kampung Donan Distrik Sausapor \\
\hline 56 & PNS & Masyarakat & Kampung Donan Distrik Sausapor \\
\hline 57 & Petani & Masyarakat & Kampung Kwoor Distrik Kwoor \\
\hline 58 & Petani & Masyarakat & Kampung Kwoor Distrik Kwoor \\
\hline 59 & Petani & Masyarakat & Kampung Ayae Distrik Miyah \\
\hline 60 & Petani & Masyarakat & Kampung Ayae Distrik Miyah \\
\hline 61 & Petani/IRT & Masyarakat & Kampung Siakwa Distrik Miyah \\
\hline 62 & Petani & Masyarakat & Kampung Siakwa Distrik Miyah \\
\hline 63 & Petani & Masyarakat & Kampung Siakwa Distrik Miyah \\
\hline
\end{tabular}




\begin{tabular}{|l|l|l|l|}
\hline $\begin{array}{c}\text { Kode } \\
\text { Informan }\end{array}$ & PEKERJAAN & \multicolumn{1}{|c|}{ Institusi } & \multicolumn{1}{c|}{ ALAMAT } \\
\hline 64 & Petani & Masyarakat & Kampung Arapi Distrik Senopi \\
\hline 65 & Petani & Masyarakat & Kampung Arapi Distrik Senopi \\
\hline 66 & Petani & Masyarakat & Kampung Arapi Distrik Senopi \\
\hline 67 & Petani & Masyrakat & Kampung Aneti, Kebar Selatan \\
\hline 68 & Petani & Masyarakat & Kampung Aneti, Kebar Selatan \\
\hline 69 & Swasta & Masyarakat & Kampung Emaus, Sausapor \\
\hline 70 & Petani & Masyarakat & Kampung Jokte ,Sausapor \\
\hline 71 & Petani & Masyarakat & Kampung Jokte, Sausapor \\
\hline 72 & Petani & Masyarakat & Kampung Bondoan, Sausapor \\
\hline 73 & Petani & Masyarakat & Kampung Bondoan, Sausapor \\
\hline 74 & Petani & Masyarakat & Kampung Bikar, Bikar \\
\hline 75 & Petani & Masyarakat & Kampung Bikar, Bikar \\
\hline 76 & Petani & Masyarakat & Kampung Bikar, Bikar \\
\hline & & $\mathbf{4 0 ~ O r a n g ~ I n f o r m a n - ~ M a s y a r a k a t ~ T a m b r a u w ~}$ \\
\hline
\end{tabular}




\section{Lampiran 2. Hasil Analisis Faktor Kunci Keberhasilan}

Faktor Internal

\begin{tabular}{|c|c|c|c|c|c|c|c|c|c|}
\hline No & Kekuatan (Strenghts) & NU & BF\% & ND & NBD & NRK & NBK & TNB & FKK \\
\hline 1. & $\begin{array}{l}\text { Luas wilayah 77\% Kawasan } \\
\text { konservasi }\end{array}$ & 5 & 0,089 & 5 & 0,446 & 3,300 & 0,295 & 0,741 & 2 \\
\hline 2. & $\begin{array}{l}\text { Ketentuan Politik Pemerintah } \\
\text { Daerah dalam visi dan misi }\end{array}$ & 5 & 0,089 & 5 & 0,446 & 3,580 & 0,320 & 0,766 & 1 \\
\hline 3. & $\begin{array}{l}\text { Adanya pemberdayaan } \\
\text { masyarakat oleh LSM dan } \\
\text { NGO dalam melestarikan dan } \\
\text { menjaga satwa yang } \\
\text { dilindungi }\end{array}$ & 3 & 0,054 & 4 & 0,214 & 2,730 & 0,146 & 0,361 & \\
\hline 4. & $\begin{array}{l}\text { Peran masyarakat dalam } \\
\text { melarang perburuan satwa } \\
\text { langka dan juga perburuan } \\
\text { menggunakan senjata api }\end{array}$ & 4 & 0,071 & 5 & 0,357 & 3,120 & 0,223 & 0,580 & \\
\hline 5. & $\begin{array}{l}\text { Adanya LSM/NGO yang } \\
\text { bergerak dalam bidang } \\
\text { lingkungan }\end{array}$ & 3 & 0,054 & 4 & 0,214 & 2,910 & 0,156 & 0,370 & \\
\hline 6. & $\begin{array}{l}\text { Adat istiadat yang masih } \\
\text { kental }\end{array}$ & 4 & 0,071 & 4 & 0,286 & 3,150 & 0,225 & 0,511 & \\
\hline 7. & $\begin{array}{l}\text { Potensi wisata yang dapat } \\
\text { dikelola menjadi objek wisata }\end{array}$ & 4 & 0,071 & 5 & 0,357 & 3,180 & 0,227 & 0,584 & 3 \\
\hline 8. & $\begin{array}{l}\text { Adanya potensi HHBK yang } \\
\text { dapat diolah menjadi obat- } \\
\text { obatan, kerajinan tangan dan } \\
\text { lainnya }\end{array}$ & 4 & 0,071 & 5 & 0,357 & 3,000 & 0,214 & 0,571 & \\
\hline 9. & Dikontrol Oleh BBKSDA & 3 & 0,054 & 3 & 0,161 & 2,880 & 0,154 & 0,315 & \\
\hline 10. & $\begin{array}{l}\text { Hasil pertanian yang } \\
\text { menunjang kehidupan } \\
\text { masyarakat }\end{array}$ & 4 & 0,071 & 4 & 0,286 & 2,720 & 0,194 & 0,480 & \\
\hline Tota & Faktor Kekuatan & & & & & & & 5,279 & \\
\hline
\end{tabular}

\begin{tabular}{|c|c|c|c|c|c|c|c|c|c|}
\hline No & Kelemahan (Weeknesses) & NU & BF\% & ND & NBD & NRK & NBK & TNB & FKK \\
\hline 1. & $\begin{array}{l}\text { Belum adanya sosialisasi } \\
\text { terkait kabupaten Tambrauw. }\end{array}$ & 1 & 0,018 & 1 & 0,018 & 3,850 & 0,069 & 0,087 & \\
\hline 2. & $\begin{array}{l}\text { Pengetahuan masyarakat } \\
\text { \&OPD masih kurang terkait } \\
\text { kabupaten konservasi. }\end{array}$ & 2 & 0,036 & 3 & 0,107 & 3,330 & 0,119 & 0,226 & 1 \\
\hline 3. & Adanya Tambang Ilegal. & 1 & 0,018 & 1 & 0,018 & 1,820 & 0,033 & 0,050 & \\
\hline 4. & $\begin{array}{l}\text { Kurangnya mutu pendidikan } \\
\text { dan Kesehatan. }\end{array}$ & 3 & 0,054 & 2 & 0,107 & 2,000 & 0,107 & 0,050 & \\
\hline 5. & $\begin{array}{l}\text { Kelembagaan adat yang belum } \\
\text { terstruktur. }\end{array}$ & 2 & 0,036 & 2 & 0,071 & 2,820 & 0,101 & 0,172 & 2 \\
\hline 6. & $\begin{array}{l}\text { Perambahan } \\
\text { penduduk/perpindahan }\end{array}$ & 2 & 0,036 & 1 & 0,036 & 2,790 & 0,100 & 0,135 & \\
\hline
\end{tabular}




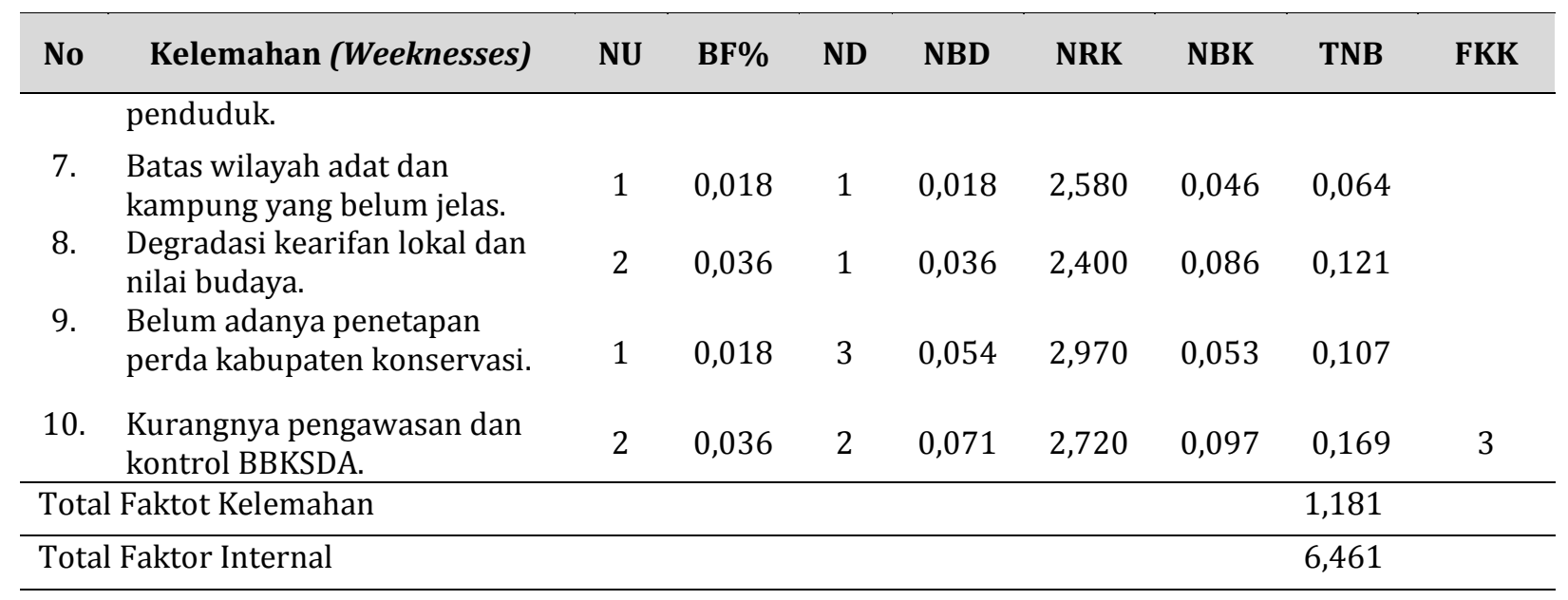

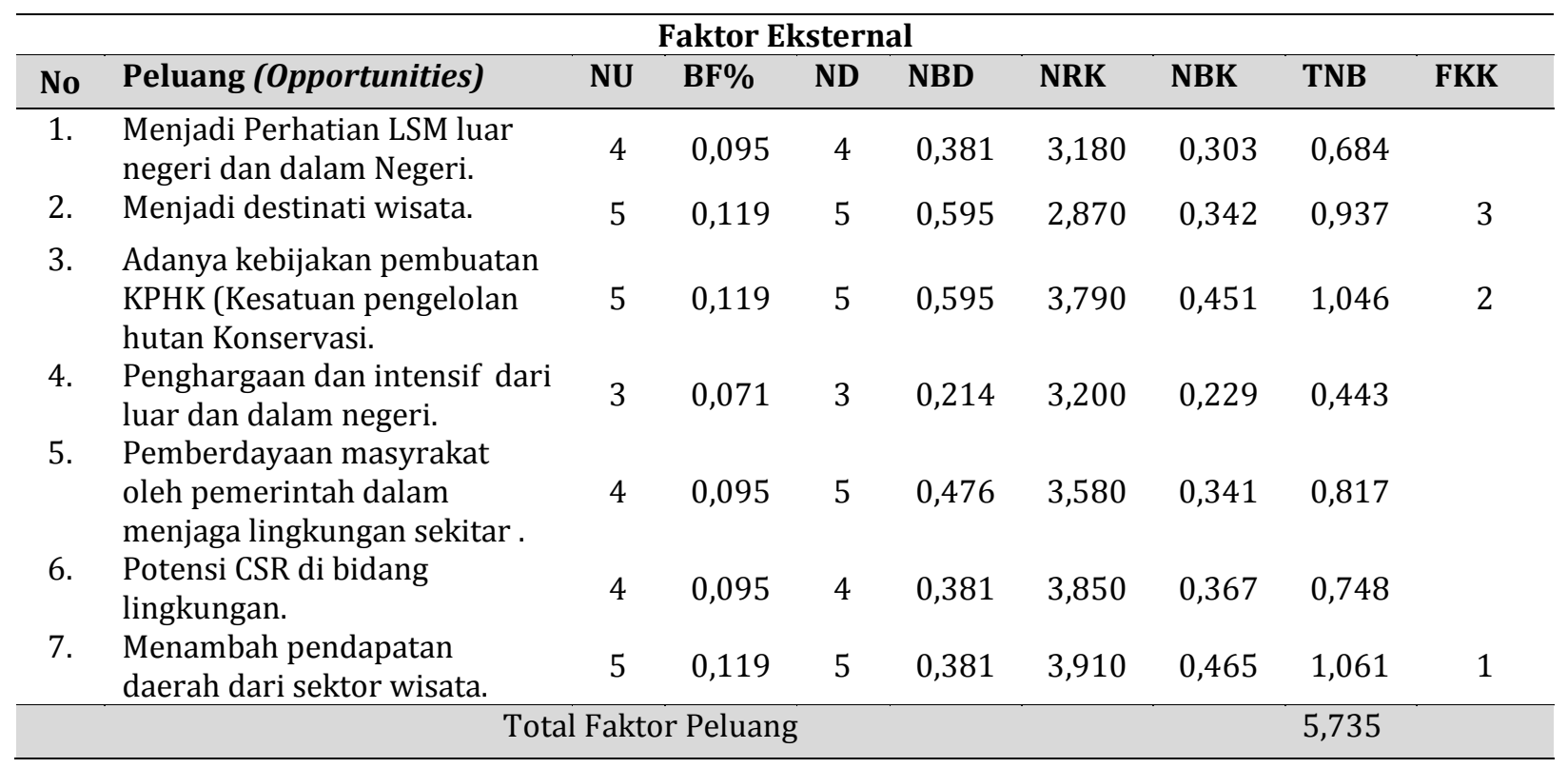

\begin{tabular}{|c|c|c|c|c|c|c|c|c|c|}
\hline No & Ancaman (Threath) & NU & BF\% & ND & NBD & NRK & NBK & TNB & FKK \\
\hline 1. & $\begin{array}{l}\text { Investasi kelapa } \\
\text { sawit,tambang dan HPH. }\end{array}$ & 1 & 0,024 & 1 & 0,024 & 2,720 & 0,065 & 0,089 & \\
\hline 2. & $\begin{array}{l}\text { Ijin investasi pemerintah } \\
\text { pusat tanpa melibatkan } \\
\text { perintah daerah. }\end{array}$ & 1 & 0,024 & 1 & 0,024 & 2,720 & 0,065 & 0,089 & \\
\hline 3. & $\begin{array}{l}\text { Degradasi kearifan lokal } \\
\text { akibat era-globalisasi. }\end{array}$ & 2 & 0,048 & 3 & 0,143 & 2,850 & 0,136 & 0,279 & 3 \\
\hline 4. & $\begin{array}{l}\text { Arus trasmigrasi yang makin } \\
\text { meningkat. }\end{array}$ & 1 & 0,024 & 2 & 0,048 & 2,800 & 0,067 & 0,114 & \\
\hline 5. & $\begin{array}{l}\text { Ketimpangan ekonomi } \\
\text { terakibat kebijakan. }\end{array}$ & 1 & 0,024 & 2 & 0,048 & 3,150 & 0,075 & 0,123 & \\
\hline 6. & Berubah-ubahnya kebijakan & 3 & 0,071 & 3 & 0,214 & 3,060 & 0,219 & 0,433 & 2 \\
\hline
\end{tabular}




\begin{tabular}{|c|c|c|c|c|c|c|c|c|c|}
\hline No & Ancaman (Threath) & NU & BF\% & ND & NBD & NRK & NBK & TNB & FKK \\
\hline \multirow[b]{2}{*}{7.} & pemerintah pusat. & & & & & & & & \\
\hline & $\begin{array}{l}\text { Pencurian Satwa dan } \\
\text { tumbuhan dari luar yang } \\
\text { masuk kedalam. }\end{array}$ & 3 & 0,071 & 4 & 0,286 & 2,730 & 0,195 & 0,481 & 1 \\
\hline \multicolumn{2}{|c|}{ Total Faktor Ancaman } & & & & & & & 1,600 & \\
\hline \multicolumn{2}{|c|}{ Total Faktor Ekternal } & & & & & & & 7,342 & \\
\hline
\end{tabular}

